\title{
Understanding Teachers' and their Learners' Perceptions about Museums Visits in South Africa
}

\author{
Mosabala M.S. \\ Department of Science and Technology Education, University of South Africa, South Africa \\ Email:mosabms@unisa.ac.za/mosabalas@yahoo.com
}

\section{Doi:10.5901/mjss.2014.v5n14p404}

\begin{abstract}
Learners' museum visits are meant to contribute to their learning. This paper considers teachers' and their learners' objectives about museum visits. Five teachers and ten learners were interviewed before and after the visit to one of four museums. Analysis of the teachers and learners responses highlighted that teachers have many different objectives which sometimes are different from those of their learners'. Teachers and learners were also found to have no clear purpose about the visits. The implications of these findings are discussed.
\end{abstract}

Keywords: museum visits; purpose of visits; teachers' perceptions

\section{Introduction and Aims}

There is a growing evidence that learning outside the classroom plays an important part in improving learners' attitude towards science as well improving gain of conceptual knowledge (Guisasola, Solbes, Barragues, Morentin, \& Moreno, 2009; Rennie \& McClafferty, 1995). There are many places that can be used by students as part of learning outside the formal classroom. Over the past four decades learners have been taken out of their formal classroom into informal learning environments where they are supposed to learn concepts that are useful as demanded by the curriculum. The field trips that schools or classes take are to aquariums, zoos, planetariums, libraries, science centres, museums and other such places. In this study the term 'museum' is used for all such centres of informal learning (Falk \& Dierking, 2000).

Even though the visits to these museums are regarded as valuable, there is a major concern about how effectively the teachers use them to promote learners' gaining of conceptual knowledge and how teachers also try to relate the visits with what learners do in classroom or the curriculum (Kisiel, 2005). Research shows that teacher hardly state their objectives for the visits and they often have different perceptions (Anderson, Lucas, \& Ginns, 2003; Cox-Petersen, Marsh, Kisiel, \& Melber, 2003; Tal, Bamberger, \& Morag, 2005)

Preparations for visits and the visits themselves are both time consuming and financially important in that they take school time for lessons and they demand both parents and the school to pay out some money. Of most interest is the fact that the visits can be valuable for learning. Teachers are the ones proposing and leading in making sure that these visits take place and become successful. Teachers are also the ones responsible for making choices as to which museum is to be visited. They probably do this with the guidance of the curriculum in most countries which means that the visit is meant to supplement what is done in classroom (Tal, 2001). Because teachers are the ones in charge of these visits, either through organising the trips or preparing learners for the visit, helping them during the trip and trying to recap on the visit when getting back to school, it therefore worth finding what objectives drive them to make the decision and how this objectives compare with those of their learners. This paper intends to answer the following questions;

- What are the teachers' objectives about the museum visits?

- How do these teachers' objectives differ from those of their learners?

\section{Background Literature}

Considerable research has been done on informal learning in countries such as Australia, Canada, the United States of America and others. Some of the studies were on how museums support learning (Dairianathan \& Subramaniam, 2011), their effect on learners' attitude (Jarvis \& Pell, 2002), nature of learning in museums (Griffin, 2004), effect of prior knowledge and interest on museum visitors learning (Falk \& Adelman, 2003) and others. 
Even though teachers are often involved in these visits with their learners, they hardly define their objectives and they often not plan for these visits (Tal, et al., 2005). This is likely to have impact on learners themselves who, on most cases, are taken to museums for learning. (Kisiel, 2005) argues teacher's motive for the visits to museums is likely to have an impact on his or her learners experience and the prospects of learning in those environments.

Packer, (2006) argues that learning in museum is driven by visitor's intrinsic motivation. According to Packer the learners do not need to have prescribed outcomes in order to learn during the museum visit. Learning is regarded as fun or leisure, and it is an experience that happens either accidentally or through the learner consciously seeking it. Even though Packer believes the entertainment part of the visit is the one which is important, Eshach (2007) has a different view. Eshach argues that when entertainment and education are brought together, education is likely to suffer. In other words the learners are likely to concentrate more on the entertainment than the education part. The teachers take learners to the museum because they have some objectives that they want these learners to achieve. If the learners consider the trip to be mainly for fun, these objectives are unlikely to be achieved (Eshach, 2007). So it is important that learners have clear objectives of the visit and this can be done during preparations.

The conceptual framework which forms the basis of this study is grounded in the notions of 'agenda' and 'motivation' used by several researchers in informal learning research (e.g. Anderson, Kisiel, \& Storksdieck, 2006; Davidson, Passmore, \& Anderson, 2010; Falk, Moussouri, \& Coulson, 1998). These and other studies show that determining visitors' motivation for their visits to museums provides insight into what and how they will learn during the visit. Relatively few studies on students' perspectives during fieldtrips have been carried out (Davidson, et al., 2010), so any insight into their learning agendas, which this paper provides, is of value for the field.

\section{Method}

This is a qualitative case study focusing on five teachers who took their learners to a museum during the time of data collection. These were teachers who were going to carry out preparation for the visit and follow up from the visit. The teachers were interviewed twice, that is before they went to museum and after they came back from the visit. The pre visit interview for each teacher was done after a classroom observation on their preparation, while the post visit interview was done after the classroom observation for their follow up activity. The interview focused on what the teacher thought about the visits to museums and reasons for taking the trips to museums. The interview schedule was piloted before carrying out the main study. Two learners from each school were selected by each teacher. These were learners that each teacher suggested would be able to express themselves well. These learners were interviewed to find out if they had the same perceptions about the objectives of the visit as their teachers. The teachers each visited one museum with their learners, all based in the vicinity of Gauteng, South Africa: the Adler Museum of Medicine at the University of the Witwatersrand (Wits), Hartebeesthoek Radio Astronomy Observatory (HartRAO), the Wits Planetarium and Sci-Bono Discovery Centre. Internal validity for the study was assured by making sure that any claim made was well-matched with the data, and evidence for this is provided in this paper.

\section{Findings}

\subsection{Purpose of the visit}

There were various reasons given by the teachers for the visits they took to the museums. Teachers gave up to four reasons for taking their learners to the museums (Table 1 ).

Table 1: Teacher purpose for the visit

\begin{tabular}{cccccccc}
\hline Teacher's name & School & Entertainment & Edutainment & Curriculum & Interactive & Career & Tradition \\
\hline Dube & Thibe & $X$ & $X$ & $X$ & - & $X$ & - \\
Jury & Martina & - & $X$ & $X$ & $X$ & - & $X$ \\
Rene & Mary & - & - & $X$ & - & - & - \\
Mango & Lodi & $X$ & - & - & - & $X$ & - \\
Koke & KTS & - & $X$ & $X$ & - & $X$ & - \\
\hline
\end{tabular}

Table 1 shows that the reasons given by the teacher for taking learners to the museum differed in many ways. For example for Jury, interactive learning that is found at HartRAO seems to be the one of the reasons why she took her 
learners there. There were more of these in her responses which showed that she was interested in exposing her learners to an interactive environment where she believed they would learn better. Another interesting observation was that of Mango. Even though Mango made it clear during the preparatory lesson that the purpose of taking the learners to Sci-Bono Discovery Centre was career based, most of her responses during the interview showed that she did not have clear reasons for taking learners to the museum. It is also worth noting that three of five teachers had three or more purposes of the visits while the other two had one (Rene) and two (Mango) purposes. The most commonly given purpose for taking the learners to the museum was related to the curriculum which was given by four teachers. Interactive and tradition were each mentioned by one teacher who also happened to be the same teacher (Jury).

\subsection{Teachers' Perspectives}

\subsubsection{Mr Dube}

Analysis of interview transcriptions and field notes revealed that to Dube the purpose of the visit was for Entertainment, Edutainment, Curriculum and Career. Most of the time Dube related the visit to the work the class was doing at school or curriculum. Despite this, it was clear that the same visit would have been part of entertainment the learners were going to have after the session. The learners had prepared meals with them which I was told they had prepared for the picnic at Zoo Lake after the session. Dube also described the visit as both interesting and educational.

Dube: $m m m h . .$. both (previous and current visit) of them are interesting. They are educational although they are dealing with different chapters and different things but they are both educational and interesting, especially planetarium.

\section{But he also described the visit to be career-related for the learners}

Dube: This type of visits? This type of visit sometimes for in a long time basis.....can sometimes pursue someone's career......yah, may be can be an astronomist or planetarian.....in other words it can pursue a learner's career.

This shows that sometimes teachers have multiple purposes for a single trip they take with their learners. Sometimes teachers' actions show another side, different from what they say they are doing. For example, Dube in the interview emphasised curriculum as the main purpose for the visit to planetarium but it was also clear from the prepared picnic that the visit was also for entertainment.

\subsubsection{Mrs Jury}

Jury's purpose of the visit was identified as Edutainment, Curriculum and Interactive. The analysis of her interview also revealed that taking the visits like the one she took with her class could be a tradition of the school.

Jury: we do a lot of outing not only with science centre but we do a number of outing in the school. They go to the one for the cave, they go to Pretoria museum. We try to do at least two outings per grade per term.

It was apparent from her response that every class had to do the visit and this could lead teachers taking the visit because it was the tradition of the school. However, Jury also gave the interactive nature of the museum as the reason why she was taking her learners to HartRAO. This is because she used the word 'interactive' fifteen times in her post visit interview. She was really emphasising it more than anything else. However, Edutainment and Curriculum were purposes that emerged during the analysis.

\footnotetext{
Jury: Because they have gone beyond what you would cover in the classroom. And that's really what we look at in an outing. It must be beneficial, educational need to the children. As well as the children enjoy it because when they enjoy it then they learn so much more.
}

Researcher: Did you know what type of exhibits they have there?

Jury: .... I did before I brought school children because I had seen it before and I knew that it was interactive and I know that it fitted in with the work I have covered at school.

Like Dube, Jury also had many reasons why she was taking learners to the museum. She emphasised the 
interactive nature of the museum but she also made it clear that the visit was related to what they were doing at school. Jury was also aware that the museum would give her learners important knowledge while at the same time enjoying themselves.

\subsubsection{Mrs Rene}

Like other teachers in the study Rene also considered the visit to be related to what they were doing at school. For her the visit was used to consolidate her Grade 6 class' learning. She had one clear purpose for the visit unlike the teachers who had several reasons for their visit to the museum.

Researcher: What do you expect them to achieve after this visit?

Rene: Just to consolidate everything that they learned, put all together.

This suggests that teachers sometimes use museum visits as a form of reinforcement of what they did with their classes or a sort of a summary.

\subsubsection{Mrs Mango}

Mango's main purpose for taking her learners to Sci-Bono was career-related. She was referring to learners making their choice of subjects for the next class depending on what career they would like to follow in future. However, the visit itself was found to be science-related. This suggests that the choices the teacher was referring to were science-related careers. It was not clear why Mango decided to take the visit at the time she did. The response she gave when she was asked was not convincing. She was not able to relate the objectives of the visit as she stated them before with the reason why the visit is done at the time it was done. The reason she gave was that they were completing the curriculum so the learners were not busy therefore they could be taken somewhere. From this response one could sense that probably the visit was an end of the year day out.

\section{Researcher: why are you doing this visit at this time?}

\section{Mango: ...learners are not that much busy... we are through with the tasks of the whole year so that's why we have to} take them somewhere.

Reasons like entertainment are usually not put explicitly by the teachers but their plans suggest that they view the visit as a sort of 'a day out' like in the case of Dube. For Mango it was clear from her responses that the visit was also a day out from school.

\subsubsection{Mrs Koke}

The purpose of the visit was related to the curriculum, for career and for learners' edutainment.

Koke: Part of the science curriculum of the grade 7 is space and they do planets and I know they show the children the distances between planets here.

Koke also took the visit because she wanted the learners to consider careers in astronomy as she believed HartRAO is also about that. She also considered the visit as a chance the learners could use to be inspired for choosing careers as scientists or astronauts as she put it.

Koke: it takes them out of their environment. Some of our children err...I must say some of them get more and more in contact with the other...outer worlds. But then some of them they go to school, go home, church, may be and then they don't go to other places at all. And it's also... a career may be job opportunity somewhere and just the normal going up into space as astronaut.

Even though Koke took the visit for curriculum and career purposes she was aware of the combination of both enjoyment and educational aspects brought by the HartRAO. As she described it, learners got a lot of information while at the same time having fun. 
Koke: It (the visit) was fun but also err...they learnt a lot. They got a lot of information and they put through in practice The teachers were generally able to give the purpose for their visit. However, they gave many reasons for the same visit.

Some of the teachers had reasons which were not same as the one described as the main purpose of the visit during preparation lessons. For an example Mango's main reason of taking her learners to Sci-Bono Discovery Centre was described as career-related. However, it was clear that she was also doing the visit for enjoyment and educational aspect.

\section{Learners' Perception about the Visit}

Table 2 summarises the purpose of the museum visit described by the learners.

Table 2: Purpose of visit as viewed by learners

\begin{tabular}{|c|c|c|c|c|c|}
\hline Learner's name & School & Entertainment & Curriculum & Career & No clear Purpose \\
\hline Lemao & Thibe & & $x$ & & \\
\hline Semaka & & & $x$ & & X \\
\hline Boyele & & $x$ & $x$ & $\mathrm{x}$ & \\
\hline Letty & Martina & $x$ & $x$ & & \\
\hline $\mathrm{Abi}$ & & $x$ & $x$ & & \\
\hline Raji & & $x$ & $x$ & & \\
\hline Boitumelo & Mary & & $x$ & & \\
\hline Thapelo & & & $x$ & & \\
\hline Thabang & & & $x$ & & \\
\hline Lefa & Lodi & & & & $x$ \\
\hline Lebo & & & & & $x$ \\
\hline Lizzy & & & & & $x$ \\
\hline Lerako & KTS & & $x$ & & $x$ \\
\hline Lesego & & & $x$ & & $x$ \\
\hline Bongy & & & $x$ & & $X$ \\
\hline
\end{tabular}

Analysis of learners' interviews shows that some of the purposes that appeared in the teachers' agendas are not there in learners' interviews. There was also emergence of a new purpose that was not observed in teachers which was 'No clear purpose'. Three learners from Thibe Primary school, Lemao, Semaka and Boyele perceive the visit to the Planetarium as related to the curriculum. It is clear that these three learners had the same perception about the visit as their teacher. However, Boyele had different perceptions from the others about the visit. He perceived the visit as a way of enjoyment. Boyele also took the visit to the Planetarium as a chance to be a scientist, and was able to relate the visit and doing science as a career. Boyele also knew that whatever they were going to do at the planetarium was related to the Solar System which was something he already knew about. However, he was interested in getting more information than he already had.

Boyele: Yah, just want to enjoy the visit ..... I'm willing to be scientist.... I'm expecting to do...to know more than I expected to know. I will be knowing how to do this work and then how the sun operates to the earth.

Semaka was a learner who at one stage of the interview seemed confused as why they were going to the planetarium.

Semaka: Because they want us to study the things. I am sure they gonna study SS and then we don't know what they are planning because as they talked about the moon, the sun but we don't know why the things that they gonna ask you there.

The learner did not seem to have any idea why they were taken to the museum. He only knew that it was something related to social science and planets which showed that learners were probably not given enough details about the visit.

The three learners from Martina Primary school that visited HartRAO were also aware that one of the reasons why they were taking the visit was that it was related to what they were doing at school. 
Letty: We are learning about stars and the planets and we are learning about solar system.

Researcher: Why do think your teacher decided to take you to this centre?

Raji: Because we want to learn about solar system and this will be in the exam at end of the year. We want to learn about all the planets and what forms them and everything about the solar system

Apart from the views that these learners had in common about the visit relating to the curriculum, they also had same views about the visit being for entertainment. For instance, they were all expecting the visit to have an element of fun according to what their teacher had told them and their own anticipation.

Letty: She told us that we gonna come and make rockets and its interesting, and we gonna have a lot of fun

Raji: We are... I am expected to like read information and launch rockets and do all funny stuff like that

Abby:(l'm expected) to launch a rocket, have fun and do all sorts of activities

Learners from Mary Primary school that visited the Adler Museum had the same perception about the visit. Three of them considered the visit to be related to the curriculum. They had anticipated observing what they dealt with at school, which was the topic of 'organ transplants' in Natural Science.

Boitumelo: Yes, like we did transplant in class and maybe we will see how transplant is done there

Thabang: She wants us to learn about body organs and transplanting kidneys and heart Thapelo: in NS we do transplant of body parts

Learners from Lodi secondary that visited the Sci-Bono Discovery Centre seemed to have no idea why they were taken on the visit. The purpose of the visit was not clear from the responses they were giving during the interview. Learners were aware that the visit was science-related but they did not seem to have any clue as to what it was that they were going to do or see at Sci-Bono Discovery Centre. They were sure that they would learn something at the centre but they could not tell what it was.

Lizzy: I am thinking our teacher brought us here because we have to learn more things about science.

Lefa: Our teacher is taking us to Sci-Bono so that so that we can learn science.

The same pattern observed in learners from Mary Primary school was also observed in KTS primary school learners. They were doing astronomy at school and they knew the visit was somehow related to the topic. This could be seen from their responses.

Lerako: We are actually doing space and astronomy now in school.

Leseko: I think she wants us to learn more about our universe and our solar system and then more about different kinds of planets.

Bongy: Errr...I think to learn about all the other...all the planets and the Earth and the sun and all that.

Even though learners had an idea that the visit might have been related to what they were doing or had done at school, there were several instances in the interviews where they seemed not to know exactly what it was that they were going to do. They were not consistent in their responses in that at one point they mentioned that the visit was related to their school, but in some instances they seemed unsure why they were being taken to the museum.

\section{A Closer Look at Teachers' and their Learners' Responses}

Table 3 shows that teachers and their learners in some cases had different views regarding the purpose of the museum visit. Learners' responses indicated that they did not have a clear purpose about museum visit and this was confirmed in some of the teachers' responses. The following; Edutainment, Interactive and Traditional were not identified in learners purposes of the visit while they were identified in teachers' responses. Dube's perception about the purpose of their visit 
to the planetarium was that it was for entertainment, edutainment, relating to the curriculum and to careers. However, learners' interviews revealed that they took the visit for entertainment, curriculum and careers. One of Dube's learners also had no clear purpose of the visit. There was a slight difference in perception about the visit. This difference could therefore be taken to show a teacher and his learners were not on same footing regarding the purpose of the visit.

Table 3: Teachers and their learners' purpose of visit

\begin{tabular}{clccccccc}
\hline School & Participants & Entertainment & Edutainment & Curriculum & Interactive & Career & No clear Purpose & Traditional \\
\hline Thibe & Dube & $\mathrm{X}$ & $\mathrm{X}$ & $\mathrm{X}$ & & $\mathrm{X}$ & & \\
& Learners & $\mathrm{X}$ & & $\mathrm{X}$ & & $\mathrm{X}$ & $\mathrm{X}$ & \\
Martina & Jury & & $\mathrm{X}$ & $\mathrm{X}$ & $\mathrm{X}$ & & & \\
& Learners & $\mathrm{X}$ & & $\mathrm{X}$ & & & & \\
Mary & Rene & & & $\mathrm{X}$ & & & & \\
& Learners & & & $\mathrm{X}$ & & & & \\
Lodi & Mango & $\mathrm{X}$ & & & & & \\
& Learners & & & & & $\mathrm{X}$ & \\
KTS & Koke & & $\mathrm{X}$ & $\mathrm{X}$ & & $\mathrm{X}$ & $\mathrm{X}$ & \\
& Learners & & & $\mathrm{X}$ & & & $\mathrm{X}$ \\
\hline
\end{tabular}

Jury had the following perception about her class visit to HartRAO; it was for edutainment, curriculum, interactive and traditional. Her learners on the other had a perception that the visit was for entertainment and related to the curriculum. Rene regarded the visit to be related to the curriculum. Her learners on the other hand had a perception that the visit was related to the curriculum. The same pattern was observed with Mango and Koke and their learners. Mango perceived the visit as being for the learners' entertainment and for career guidance. Her learners on the other hand did not have a clear purpose about the visit. Koke's reasons for taking the learners to the visit were for edutainment, curriculum and for careers. Her learners' interview analysis revealed two subcategories; curriculum and no clear purpose.

There was only a single instance where teacher's objectives about the visit were exactly the same with those of the learners. This suggests that most teachers did not do enough work with their learners so that they could share the same view about the visit. The preparation done was possibly not adequate to make both teachers and their learners have same viewpoint about the visit.

\section{Teachers' Perceptions: Discussion}

Teachers gave different reasons why they took their learners to museums and why they thought it is important to take such visits with their classes. Teachers' responses were categorised into objectives like Entertainment, Edutainment, Curriculum, Interactive, Career and Traditional. Teachers gave more than one purpose for the visit during the interview. This might mean that teachers either had multiple purposes for the visit, or they were not sure of the purpose of the visit, or that they somehow did not think about the exact purpose of the visit. Some of the teachers were hesitant to give responses to why they were taking the visits which also might mean that they were probably not certain about the purpose of the visit. For example, Mango made it very clear that she was taking the learners to Sci-Bono Discovery Centre for career purposes. Even her preparation was mainly on careers. But her interview revealed that another purpose for her class visit was also Entertainment. This might be taken to mean uncertainty rather than her having multiple purposes for the trip.

Dube's learners were seen with some bags full of drinks and some food stuff. Asked why they were carrying some much food stuff while they were visiting a planetarium which was just an hour away from school, they mentioned that they were on their way to the zoo for picnic. Apparently Dube and his colleagues had organised an end of the year picnic for the learners. The picnic was a sort of farewell for those who would be leaving the school. It was difficult to understand how Dube expected the learners to learn anything during the visit while the destination was a picnic at the zoo. It will possibly be interesting for future research to try and find out what effect visiting several places in a single trip has on the learners learning in those places. Jury told me that her school planned the visits each class would take and there were a certain number of visits each would be allocated per term.

Jury: we do a lot of outing not only with science centre but we do a number of outings in the school. They go to the one for the cave, they go to Pretoria museum. We try at least two outings per grade per term...... they go to Constitutional Hill the grade $6 s$ as well. This is err...history related... they go to the Theatre, they went to...the grade $5 s$ have been to 
Parktown Heritage Theatre that is history related. They have been on a tour to Coca-Cola factory.... the Weather station, that is with Ann... Weather station that is excellent outing.

It was possible that some of visits were just done because it was the tradition of the school to take visits every term. School tradition was therefore considered to be one of the reasons why Jury took her learners to the museum. Almost all the teachers (except Mango) mentioned the content or the subject they were doing at school as one of the reasons for taking their class to museum. It is likely that teachers were aware of the learning opportunities that museums provide to their learners. Teachers were able to describe how the visit was related to the topic they were doing at school. (Michie, 1998), in his study to find factors that influence science teachers to organise and conduct visits, found that some of the reasons teachers gave for taking the visit included their belief that visits give learners hands-on, real life experiences which they could not get from the laboratory or normal classroom teaching. Teachers in Michie's study also believed that the activities at the museums improve learners understanding and their attitudes towards science. On other hand, (Falk, et al., 1998) reported some objectives for visits included education, a social event, entertainment and practical issues and they believe that these objectives affect how visitors learn. These different objectives for visiting a museum show that people go to museums with different objectives. In this study a similar pattern was observed as teachers gave various reasons for visiting as shown by extracts from Koke's interview:

Koke: But I know there are other places but prefer this because children enjoy

Koke: It was fun but also err...they learnt a lot. They got a lot of information and they put through in practice.

Researcher: Why do you think these types of visits are important in general?

Koke: it takes them out of their environment. Some of our children get more in contact with the outer worlds... and it's also... a career may be job opportunity somewhere and just the normal going up into space as astronaut.

Falk et al. (1998) also reported that usually a visitor would express several of these objectives not one. This was similar to this study where all the teachers in the study gave more than one reason for visiting. Anderson, Kisiel, \& Storksdieck, (2006) describe the situation of having multiple objectives for visiting the museums as a sign that teachers were aware of the rich opportunity provided by the visits. On other hand, Storksdieck, Kaul, \& Werner (2006) referred to this multitude of objectives as conflicting. It was not clear from our study whether multiple objectives given by the teachers was an indication that teachers were aware of the opportunities provided by the museums or they did not know the specific objectives of the visits. Further research in this area would be valuable in South Africa. The study done by Kisiel (2005) report that most of the teachers (90\%) stated that a connection to the curriculum was an important reason for the visit. These results were similar to those of this study where four of the five of teachers reported content or subject they did at school as one of the reasons they visited the museums with their classes.

\section{Learners' Perceptions: Discussion}

Learners were interviewed in order to get the idea of whether they know why they were taken to museum visits by their teachers. It is worth noting that not all categories emerged from teachers' interviews were found in learners interview. There are learners who did not know why they were taking the visit. These were described to have 'No Clear Purpose'. This shows that sometimes teachers take their learners to museum with a certain purpose but the learners themselves do not have any idea why they are taken to the museums. These findings are similar to one of the cases in Davidson, et al's study, where "students ... had vague ideas about what they were supposed to learn on the trip" (2010, p. 132). If learners are not sure why they go on a field trip there is high possibilities that they would not achieve what their teachers want them to achieve. It is the responsibility of teachers to make sure that their learners know the purpose the field trip before they go to such trips. These findings substantiate what Griffin (1998) found in her study. Griffin found that $42 \%$ of the learners interviewed did not know the purpose for the excursion they had. Griffin also found that even some teachers did not have a clear purpose for the excursion which is different from the findings of this study where all the teachers have some purpose their field trips. The results of this study show that teachers are not consistent in terms of having clear purposes for taking their learners for the field trips. This is likely to affect their learners who also will not know the reasons for taking the trips. 


\section{Summary}

The results indicate that the teachers did not convey to their learners clear, explicit purposes or objectives for the visit they took. By contrast, in schools groups where the visit was related to the topic being done at school, both the teachers and learners were able to articulate the purpose of the visit. Teachers were giving so many objectives of the visit that could be taken to show they were not sure about the purpose of the visits. Teachers were also not able to give their learners a broad picture of the visit to help the learners see the link between what they were doing at school, the visit itself and what they would do after the visit. One of the reasons why teachers could not do that could be that even teachers themselves did not have the whole, clear, coherent picture about the visit.

The fact that learners sometimes go to museums not knowing why they are doing it should be a concern for teachers. Teachers therefore have to make sure that their learners are aware of the purpose for the visit. We believe this can help learners to be focused when they get to the museums and therefore be in a better position to achieve what the trip is meant for. This paper shows that some teachers are not consistent when it comes to having clear objectives for taking their learners to the visits, and echoes Davidson, et al. (2010) who stress that it is very important for teachers to plan their trips clearly, and relate them to the classroom curriculum. Teachers should visit the museum before planning so that they could know what the museum provides beforehand, and this can help to improve their own teaching practices.

\section{References}

Anderson, D., Kisiel, J., \& Storksdieck, M. (2006). Understanding Teachers' Perspectives on Field Trips: Discovering Common Ground in Three Countries. Curator: The Museum Journal, 49(3), 365-386.

Anderson, D., Lucas, K., \& Ginns, I. (2003). Theoretical Perspectives on Learning in an Informal Setting. Journal of Research in Science Teaching, 40(2), 177-199.

Cox-Petersen, A. M., Marsh, D. D., Kisiel, J., \& Melber, L. M. (2003). Investigation of Guided School Tours, Student Learning, and Science Reform Recommendations at a Museum of Natural History. Journal of Research in Science Teaching, 40(2), 200-218.

Dairianathan, A., \& Subramaniam, R. (2011). Learning about Inheritance in an Out-of-School Setting. International Journal of Science Education, 33(8), 1079 - 1108.

Davidson, S. K., Passmore, C., \& Anderson, D. (2010). Learning on zoo field trips: The interaction of the agendas and practices of students, teachers, and zoo educators. Science Education, 94(1), 122-141.

Eshach, H. (2007). Bridging in-school and out-of-school learning: Formal, non-formal, and informal education. Journal of science education and technology, 16(2), 171-190.

Falk, J. H., \& Adelman, L. M. (2003). Investigating the Impact of Prior Knowledge and Interest on Aquarium Visitor Learning. Journal of Research in Science Teaching, 40(2), 163-176.

Falk, J. H., \& Dierking, L. D. (2000). Learning from museums: Visitor experiences and their making of meaning. Walnut Creek, CA: Altamira Press

Falk, J. H., Moussouri, T., \& Coulson, D. (1998). The Effect of Visitors' Agendas on Museum Learning. Curator, 41(2), $107-120$.

Griffin, J. (2004). Research on Students and Museums: Looking More Closely at the Students in School Groups. Science Education, 88(Supplement 1), S59-S70.

Guisasola, J., Solbes, J., Barragues, J.-I., Morentin, M., \& Moreno, A. (2009). Students' Understanding of the Special Theory of Relativity and Design for a Guided Visit to a Science Museum. International Journal of Science Education, 31(15), 2085 - 2104.

Jarvis, T., \& Pell, A. (2002). Effect of the Challenger Experience on Elementary Children's Attitudes to Science. Journal of Research in Science Teaching, 39(10), 979-1000.

Kisiel, J. (2005). Understanding Elementary Teacher Motivations for Science Fieldtrips. Science Education, 89(6), 936-955.

Michie, M. (1998). Factors influencing secondary science teachers to organise and conduct field trips. Australian Science Teachers' Journal, 44(4), 43-50.

Packer, J. (2006). Learning for Fun: The Unique Contribution of Educational Leisure Experiences. Curator: The Museum Journal, 49(4), 329-344.

Rennie, L. J., \& McClafferty, T. P. (1995). Using Visits to Interactive Science and Technology Centers, Museums, Aquaria, and Zoos to Promate Learning in Science. Journal of Science Teacher Education, 6(4), 175-185.

Storksdieck, M., Kaul, V., \& Werner, M. (2006). Tackling it together: Local partnerships to improve field trip experiences. Paper presented at the NARST 2006 Annual Meeting, San Francisco, CA.

Tal, R. T. (2001). Incorporating field trips as science learning environment enrichment-an interpretive study. Learning environments research, 4(1), 25-49.

Tal, R. T., Bamberger, Y., \& Morag, O. (2005). Guided School Visits to Natural History Museums in Israel: Teachers' Roles. Science Education, 89, 920-935. 